\title{
Is There Any Relationship Between Thyroid Function Abnormalities, Thyroid Antibodies and Development of Gestational Diabetes Mellitus (GDM) in Pregnant Women?
}

\author{
Gebelikte Tiroid Fonksiyon Bozuklukları, Tiroid Antikorları ve Gestasyonel \\ Diabetes Mellitus (GDM) Gelişimi Arasında Bir Illişki Var Mıdır?
}

\section{U. Yasemin SERT ๑, Gul Nihal BUYUK ๑, Yaprak ENGIN USTUN ๑, A. Seval OZGU ERDINC ๑}

Ethics Committee Approval: This study was approved by the University of Health Sciences, Zekai Tahir Burak Women's Health Care Training and Research Hospital, Clinical Studies Ethics Committee, 28 November 2018, 2018/20.

Conflict of interest: The authors declare that they have no conflict of interest. Funding: None.

Informed Consent: Informed consent was taken from the patients enrolled in this study.

\begin{abstract}
Objective: To determine the levels of thyroid-stimulating hormone (TSH), thyroxin (T4), triiodothyronine (T3), anti-thyroid peroxidase (anti-TPO), anti-thyroglobulin (anti-TG) and renal iodine excretion (RIE) in the first trimester of the pregnancy and to estimate the risk of developing GDM in these patients.

Method: The levels of TSH, T3, T4, anti-TPO, anti-TG, and RIE were retrospectively evaluated. A total of 312 pregnant women were included in the study (GDM (-) group $n=240, G D M(+)$ group $n=62$ ). Diagnosis of GDM was made according to the recommendation of American Diabetes Organization (ADA). The association between thyroid dysfunction and GDM was evaluated. Results: Our study included a total of 302 women. Sixty-two of these women were diagnosed as GDM (62/302 $=20.5 \%)$. When compared with the GDM (-) group the mean TSH level $(2.02 \mathrm{vs}$ $4.13 p=0.019)$, anti-TPO positivity ( $8.3 \%$ vs $30.64 \% p=0.044$ ), anti-TG positivity ( $8.3 \%$ vs $19.4 \%$ $p=0.019$ ) and RIE (156 vs $178 p=0.017$ ) were significantly higher in the GDM (+) group. TSH levels were statistically significantly higher in patients with positive anti-TPO levels $(P=0.045)$. Conclusion: Elevated TSH levels, TPO and TG antibody positivity rates were more frequent among the patients with GDM. These results may be a guide to perform routine thyroid function tests for patients with increased risk of GDM, on the other hand, they will alert the physicians for GDM progression and ensure taking preventive attempts for the patients who have thyroid disorder, especially those with positive thyroid antibodies in the first trimester of the pregnancy.
\end{abstract}

Keywords: Anti-TG, Anti-TPO, GDM, pregnancy, renal iodine excretion, thyroid function disorder Öz

Amaç: Gebeliğin ilk trimesterında tiroid stimule edici hormon (TSH), tiroksin (T3), triiodotironin (T3), anti- tiroid peroksidaz (anti-TPO), anti tiroglobulin (anti-TG) ve renal iyot atılımını (RIA) saptamak ve bu hastalarda gestasyonel diyabet (GDM) gelișme riskini belirlemek.

Yöntem: TSH, T3, T4, anti-TPO, anti-TG ve üriner iyot atılımı düzeyleri retrospektif olarak değerlendirildi. Toplamda 302 kadın çalıșmaya dahil edildi (GDM (-) grup $n=240, G D M(+)$ grup $n=62$ ). GDM tanısı Amerikan Diyabet Derneğinin (American Diabetes Organization (ADA) önerileri doğrultusunda yapıldı. Tiroid disfonksiyonu ve GDM arasındaki ilişki değerlendirildi.

Bulgular: Calışmamıza toplamda 302 kadın dahil edildi. Bu kadınlardan altmış ikisi GDM tanısı aldı (62/302=\%20.5). Ortalama TSH düzeyi (2.02 vs 4.13 p=0.019), anti-TPO (8.3\% vs 30.64\% $p=0.044)$, anti-TG pozitifliği (8.3\% vs $19.4 \% p=0.01)$ ve RIA düzeyleri (156 vs $178 p=0.017)$ $G D M(+)$ saptanan grupda anlamlı olarak yüksek saptandı TSH, anti-TPO pozitif olan kadınlarda daha yüksek olma eğiliminde olup, bu fark istatistiksel olarak anlamlı saptandı $(P=0.045)$.

Sonuç: Artmış TSH düzeyi ve anti-TPO, TG antikor pozitifliği GDM'li hastalarda daha sık olarak gözlenir. Çalışmamızın sonuçları, artmış GDM riski olan hastalarda rutin tiroid fonksiyon testi ile değerlendirme konusunda yol gösterici olacak, diğer taraftan, gebelikte tiroid fonksiyon bozukluğu, özellikle ilk trimester'da tiroid antikor pozitifliği olan hastalarda GDM gelişimi açısından dikkatli olunması ve önleyici adımların atılması sağlanacaktır.

Anahtar kelimeler: Anti-TG, Anti-TPO, GDM, gebelik, renal iyot atılımı, tiroid fonsiyon bozukluğu

(c) Copyright Istanbul Medeniyet University Faculty of Medicine. This journal is published by Logos Medical Publishing.

Licenced by Creative Commons Attribution-NonCommercial 4.0 International (CC BY-NC 4.0)
Received: 27 May 2020

Accepted: 9 August 2020

Online First: 30 September 2020

Corresponding Author: A.S. Ozgu Erdinc ORCID: 0000-0002-6132-5779

University of Health Sciences,

Zekai Tahir Burak Women's Health Care Training and Research Hospital, Department of Obstetrics and Gynecology, Ankara, Turkey

sevalerdinc@gmail.com

U.Y. Sert

ORCID: 0000-0003-0862-4793

G.N. Buyuk

ORCID: 0000-0003-4405-2876

Y. Engin Ustun

ORCID: 0000-0002-1011-3848

University of Health Science,

Zekai Tahir Burak Women's

Health Care Training and Research

Hospital, Department of

Obstetrics and Gynecology, Ankara, Turkey 


\section{INTRODUCTION}

Thyroid metabolism and urinary iodine levels are subjected to significant alterations due to hormonal and metabolic status during pregnancy ${ }^{1,2}$. In the first trimester of the pregnancy, human chorionic gonadotropin (hCG) hormone stimulates thyroid-stimulating hormone (TSH) because of its structural similarity ${ }^{2}$. This stimulation results in higher thyroxin (T4) and triiodothyronine (T3) levels, while TSH tends to decrease ${ }^{2}$. Increasing estrogen levels and associated production of thyroid-binding globulin (TBG), larger plasma volume, increasing renal iodine excretion (RIE), and higher thyroid metabolism are responsible for changes in thyroid functions during pregnancy ${ }^{3}$. Hypothyroidism, especially in the first trimester of the pregnancy, is associated with poor perinatal results. Overt hypothyroidism is associated with fetal death, miscarriage, gestational hypertension, including eclampsia, preeclampsia, preterm labor, and low birth weight ${ }^{4}$. Although there is a relation between subclinical hypothyroidism and the poor obstetric outcome, this relation tends to become more robust by increasing TSH levels ${ }^{5}$.

Thyroid autoantibodies (TAs) are seen in 2 to $17 \%$ of the pregnant population ${ }^{6}$. This wide range of prevalence is affected by ethnicity, age, and dietary iodine intake ${ }^{6}$. Recent studies have indicated that patients with positive TA during early pregnancy tend to have higher TSH levels as pregnancy progresses. However, antibody levels in the third trimester are decreased by $60 \%$ compared to the first trimester ${ }^{6}$. Studies have shown an association between thyroid antibodies and pregnancy loss, premature labor, postpartum thyroiditis, and placental abruption ${ }^{7,8}$. The recent recommendation of the American Thyroid Association (ATA) in 2017 contains different treatment advices according to the levels of thyroid antibodies to improve obstetric outcomes of pregnant women diagnosed as subclinical hypothyroidism ${ }^{6}$.

Iodine is one of the required elements of thyroid hormone synthesis. The deficiency of iodine in pregnant women causes poor pregnancy outcomes and impaired fetal neurocognitive development ${ }^{9}$. RIE is the gold standard reflecting the iodine status ${ }^{10}$.

GDM was historically described as glucose metabolism disorder with different severity, which has been recently recognized in the pregnancy, and American Diabetes Organization (ADA) revised the definition by adding "Diabetes Mellitus (DM), which occurred in the second or third trimester of the pregnancy" ${ }^{11}$. International Diabetes Federation (IDF) announced that $16.2 \%$ of pregnancies with live births present with hyper-glycemia, and $85 \%$ of these cases are diagnosed as GDM ${ }^{11}$. The overall prevalence of GDM is between 1 and $14 \%$, according to the population's metabolic, genetic, and lifestyle characteristics ${ }^{12}$. GDM typically resolves after the delivery. Up to $70 \%$ of these women are diagnosed as type 2 DM in 6 weeks to 28 years postpartum, and less than $10 \%$ need to use insulin after the pregnancy ${ }^{13}$. Studies have demonstrated that TA are more frequent in patients with type $1 \mathrm{DM}^{14}$. We can describe the increased frequency with enhanced immune response and associated multi-organ autoimmune disorders ${ }^{13}$. Although the pathophysiologic mechanism of GDM rests on relative insulin deficiency and increased insulin resistance, autoimmune pathways like type 1 DM might also have a part in a group of women with GDM ${ }^{11}$. Recent studies demonstrated that hypo-thyroxinemia is more frequent in GDM patients, while a few data focus on thyroid immunity and $\mathrm{GDM}^{13}$.

In this retrospective cohort study, we purposed to analyze the relationship between GDM and thyroid disorders and thyroid autoimmunity.

\section{MATERIAL and METHODS}

The patients studied in this retrospective cohort study were pregnant women attending an antenatal outpatient clinic of The Department of Ob- 
stetrics and Gynecology of the Health Sciences University, Zekai Tahir Burak Women's Health Care Training and Research Hospital between December 2018 and December 2019. Institutional Review Board has confirmed the survey in terms of ethical suitability.

Approximately 302 women whose TSH, T3, T4, TA (anti-thyroid peroxidase (anti-TPO), antithyroglobulin (anti-TG)), RIE, and fasting plasma glucose (FPG) levels in their first trimester were included in the study. All the women without risk factors for GDM and first-trimester $\mathrm{FPG}<92$ were evaluated with a $50-\mathrm{g}$ glucose challenge test (GCT) between 24 and 28 weeks of pregnancy as the first step regardless of the fasting situation. Blood glucose level of $\geq 140 \mathrm{mg} / \mathrm{dl}$ after GCT was accepted positive, and women with positive GCT were evaluated with a $100-\mathrm{g}$ oral glucose tolerance test (OGTT). As a routine procedure after an overnight fasting for $12 \mathrm{~h}$, venous plasma values of fasting, and 1, 2 and 3 hours after an oral load of $100-\mathrm{g}$ glucose intake were calculated Blood glucose was calculated by enzymatic procedure using Hitachi Cobas ${ }^{\circledR}$ analyzer. Glucose level was studied by using glucose oxidase kit HK Gen.3. The reading level varied between 2 and $750 \mathrm{mg} /$ dL. GDM was diagnosed if two or more plasma glucose levels equal or exceed the below-indicated values after 100 -g oral glucose load following overnight fasting of 8-14 hours: FPG value of 95 mg/dl, postprandial 1-, 2-, and 3- hour blood glucose levels of 180,155 , and $140 \mathrm{mg} / \mathrm{dl}$, respectively.

The patients were compared in GDM (-) $(\mathrm{n}=240)$ and GDM (+) $(n=62)$ groups respectively. All the patients included these groups were evaluated using thyroid tests, including TSH, T3, T4, antiTPO, anti-TG, and RIE. The relationship between thyroid tests and groups was determined. Thyroid metabolism tests were measured in the ISO-certified laboratory of our hospital. TSH levels varied between 0.005 and $100 \mathrm{mU} / \mathrm{l}$, fT3 between 0.3 and $10 \mathrm{nmol} / \mathrm{L}$ and fT4 between 0.101 and 7.77
ng/dL. Levels of anti-TPO and anti-TG varied between 5-600 IU/ml, and 10-4000 IU/ml, respectively. RIE $(\mu \mathrm{g} / \mathrm{l})$ was determined using the plasma mass spectrometry method (Spectroquant ${ }^{\circledR}$ ). RIE varied between 26 and $705 \mu \mathrm{g} / \mathrm{l}$.

SPSS (Statistical Package for the Social Sciences) version 22.0 program was utilized for statistical analysis of the data. The normality of the continuous variables was tested using the KolmogorovSmirnov test. The Student's t-test was used for normally distributed values, and the continuous variables were expressed as the mean $\pm S D$. MannWhitney U-test was used for non-normal distributed values. The data were expressed as median, mean, and maximum. $\mathrm{P}<0.05$ was considered as statistically significant. The area (AUC) under the receiver operating characteristic (ROC) curve was used to evaluate the TSH's performance to predict GDM, and the optimal cut-off point was calculated. The cut-off value to predict the development of GDM was examined by using Youden's index. The sensitivity, specificity, positive predictive value (PPV), and negative predictive value (NPV) with their associated $95 \%$ confidence interval $(\mathrm{CI})$ were determined.

\section{RESULTS}

The study included 302 pregnant women. Diagnosis of GDM was made in 62 of these women $(62 / 302=20.5 \%)$ (Figure 1$)$. The mean ages were not significantly different between GDM (+), and

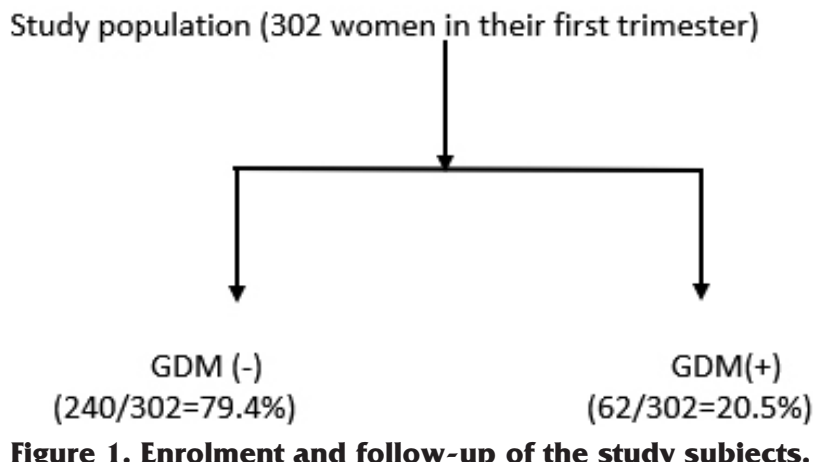

GDM: Gestational diabetes mellitus 
GDM (-) groups $(28.24 \pm 5.52$ in the GDM (+) group, and $27.89 \pm 4.86$ in the GDM (-) group $(p=0.620)$. Gravidity, parity, and BMI were not statistically significant between the groups $(p=0.146, p=0.256$, and $p=0.646$, respectively) (Table 1 ). TSH levels were significantly higher in GDM (+) group [4.13 (min-max values: 0.01-23.00) in GDM (+) group and 2.02 (min-max values: 0.01-11.34) in GDM (-) group $(p=0.019)]$ (Table 2$)$. Anti-TPO positivity was found in 39 women, and 27 of these women were diagnosed as GDM (69.2\%). The rate of anti-TPO positivity was 30.64\% (19/62) for the GDM (+) group and 8.3\% (20/240) for the GDM (-) group with a statistically significantly intergroup difference $(p=0.044)$ (Table 2$)$. Anti-TG was positive in 12 patients in the GDM (+) group $(12 / 62=19.4 \%)$ and 20 patients in the GDM (-) group $(20 / 240=8.3 \%)$. Anti-TG was significantly more frequently detected in the GDM (+) group $(p=0.019)$ (Table 2$)$. RIE was significantly higher in the GDM (+) group ( $p=0.017$ ) (Table 2$)$. The relationship between TSH levels and thyroid autoan-

Table 1. Demographic characteristics of the groups.

\begin{tabular}{llll}
\hline & $\begin{array}{l}\text { GDM (-) } \\
(\mathbf{n = 2 4 0 )}\end{array}$ & $\begin{array}{l}\text { GDM (+) } \\
(\mathbf{n = 6 2 )}\end{array}$ & P value \\
\hline Age (years) & $27.89 \pm 4.86$ & $28.24 \pm 5.52$ & 0.620 \\
Gravidity & $3(1-5)$ & $2(1-4)$ & 0.146 \\
Parity & $1(0-4)$ & $2(0-3)$ & 0.256 \\
BMI $\left(\mathrm{kg} / \mathrm{m}^{2}\right)$ & $27(19-37)$ & $26.4(22-33)$ & 0.646 \\
\hline
\end{tabular}

BMI: Body mass index, GDM: Gestational diabetes mellitus

Table 2. Laboratory results of the groups.

\begin{tabular}{llll}
\hline & $\begin{array}{l}\text { GDM (-) } \\
(\mathbf{n}=\mathbf{2 4 0})\end{array}$ & $\begin{array}{l}\text { GDM (+) } \\
(\mathbf{n}=62)\end{array}$ & P value \\
\hline TSH (mU/l) & $2.02(0.01-11.34)$ & $4.13(0.01-23)$ & $0.019^{*}$ \\
T3 (nmol/L) & $2.01(0.01-5.60)$ & $2.02(0.012-4.40)$ & 0.948 \\
T4 (ng/dL) & $1.97(0.01-4.40)$ & $2.00(0.01-12.23)$ & 0.777 \\
Anti-TPO & $20(8.3 \%)$ & $19(30.64 \%)$ & $0.044^{*}$ \\
positive & $20(8.3 \%)$ & $12(19.4 \%)$ & $0.019^{*}$ \\
$\begin{array}{l}\text { Anti-TG } \\
\text { positive }\end{array}$ & $156(99-212)$ & $178(139-392)$ & $0.017^{*}$ \\
RIE ( $\mu$ g/L) & 150
\end{tabular}

${ }^{*}$ Statistically significant ( $p>0.05$ )

GDM: Gestational diabetes mellitus, TSH: Thyroid-stimulating hormone, T4: Thyroxin, T3: Triiodothyronine, Anti-TPO: Antithyroid peroxidase, Anti-TG: Anti-thyroglobulin, RIE: Renal iodine excretion tibodies was also evaluated. There was no statistically significant difference between antibody positive and negative groups, although TSH tended to be higher among patients with anti-TG and anti-TPO antibodies $(p=0.917$ and $p=0.542$, respectively). AUC, and ROC were used to evaluate the performance of TSH to predict GDM, and the

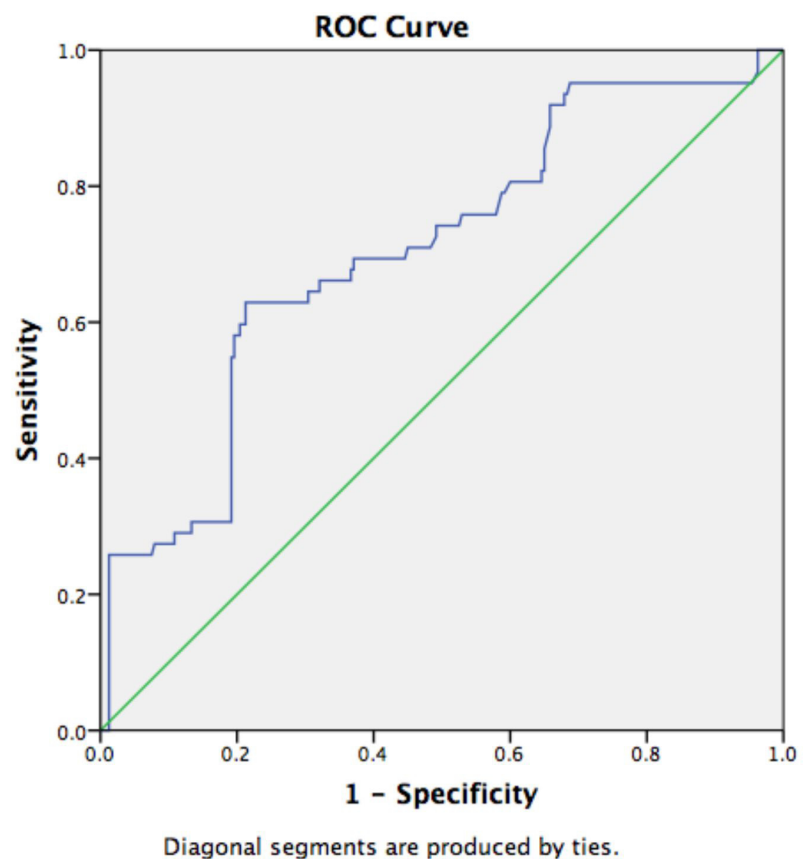

Figure 2. Area under ROC curve analysis of the TSH to predict GDM.

TSH: Thyroid-stimulating hormone, GDM: Gestational diabetes mellitus, ROC: Receiver operating characteristic

Table 3. The diagnostic performance of thyroid-stimulating hormone (TSH) to predict gestational diabetes mellitus (GDM).

\begin{tabular}{ll}
\hline & $\begin{array}{l}\text { Cut-off for } \\
\text { TSH=5.33 } \mathbf{~ m u / l}\end{array}$ \\
$\begin{array}{l}\text { Sensitivity (\%) } \\
(95 \% \mathrm{CI})\end{array}$ & $62.9(49.6-74.5)$ \\
$\begin{array}{l}\text { Specificity (\%) } \\
\text { Positive likelihood ratio } \\
(95 \% \mathrm{CI})\end{array}$ & $78.7(72.9-83.6)$ \\
$\begin{array}{l}\text { Negative likelihood ratio } \\
(95 \% \mathrm{CI})\end{array}$ & $2.96(2.17-4.03)$ \\
$\begin{array}{l}\text { Positive predictive value (PPV) }(\%) \\
(95 \% \mathrm{CI})\end{array}$ & $0.47(0.33-0.65)$ \\
$\begin{array}{l}\text { Negative predictive value (NPV) }(\%) \\
(95 \% \mathrm{CI})\end{array}$ & $89.15(83.97-92.85)$ \\
Diagnostic accuracy (\%) & 75.4 \\
\hline
\end{tabular}

CI: Confidence interval 
optimal cut-off point was calculated ( $\mathrm{AUC}=0.705$ and $\mathrm{p}<0.001$ ) (Figure 2). The sensitivity, specificity, PPV, and NPV with their associated 95\% Cls were determined. According to Youden's index for TSH, the best accuracy was with the cut-off value of $5.33 \mathrm{mU} / \mathrm{l}$ with a sensitivity of $62.9 \%(95 \%$ CI $49.6-74.5)$ and a specificity of $78.7 \%(95 \% \mathrm{CI}$ 72.9-83.6). PPV and NPV were $43.33 \%(95 \% \mathrm{CI}$ 33.05-54.18), and $89.15 \%$ (95\% Cl 83.97-92.85), respectively (Table 3 ).

\section{DISCUSSION}

In the present study, to determine the association between thyroid dysfunction and GDM, the thyroid function tests of pregnant women, including TSH, T3, T4, TA, and RIE were examined. In our study, GDM patients had significantly higher TSH levels, more frequent anti-TPO and anti-TG antibodies, and RIE.

The association between thyroid disorders and DM has been demonstrated in the literature ${ }^{14}$. On the one hand, thyroid hormones have significant effects on glucose metabolism; and on the other hand, thyroid function tests are affected by diabe$\operatorname{tes}^{14}$. This interaction might be theoretically demonstrated with any kind of glucose and thyroid metabolism dysfunction.

The prevalence of thyroid diseases is higher in the diabetic population, especially in people with type $1 \mathrm{DM}^{14,15}$. Several mechanisms have been accused of this relationship. Hyperthyroidism is known as a promoter of hyperglycemia because of defective insulin releasing mechanisms, increased gut absorption, enhanced endogenous glucose production, catecholamine, and glucagon mediated gluconeogenesis ${ }^{16}$. Hypothyroidism is also known as sufficient for glycemic regulation ${ }^{14}$. Decreased gluconeogenesis and insulin requirement are frequent in hypothyroid patients. However, hypothyroidism is known as an insulin-resistant condition ${ }^{14}$. Autoimmune thyroid disorders are the most frequent immunologic disorder among the patients with type $1 \mathrm{DM}$, and this relationship might be explained with shared immune mechanisms between autoimmune diseases ${ }^{17}$. Studies have demonstrated that $6-24 \%$ of patients with type $1 \mathrm{DM}$ and 3-6\% of patients with type 2 DM suffer from hypothyroidism, while 1-2\% of diabetic patients present with hyperthyroidism ${ }^{18}$. Routine thyroid screening is recommended for people with type $1 \mathrm{DM}$ because of increased rates of concomitancy, while the studies evaluating the association between GDM and thyroid disorders are lacking ${ }^{19}$.

In the pregnancy, increases, and decreases in blood glucose levels are under the control of hormones, such as hCG, estrogen, TBG, placenta-derived insulin, and placental lactogen, that can be changed by the alteration of thyroid hormone levels $^{20}$. Increased insulin resistance and pregnancyinduced autoimmune mechanisms may result in $\mathrm{GDM}^{21}$. In this study, it is hypothesized that thyroid disorders are more frequent in GDM patients. This association might be due to the interaction of metabolic alterations or common immunologic mechanisms.

Studies have demonstrated that autoimmune mechanisms could play a role in the development of GDM in some patients ${ }^{11}$. Diabetes-related antibodies, including islet cell antibodies, insulin autoantibodies, glutamic acid decarboxylase antibodies, and zinc transporter 8 can be presented in some GDM cases. The existence of diabetesrelated autoantibodies suggests a concomitant immune predisposition to other autoimmune disorders such as thyroid autoimmunity ${ }^{11}$. Murgia et al. ${ }^{21}$ demonstrated that $38.8 \%$ of GDM patients have at least one of these antibodies. In our study, the immune basis of GDM was not evaluated, and this is one of the weaknesses of the study. Thyroid dysfunction due to the increased insulin resistance is another possible mechanism that may explain hypothyroidism and $\mathrm{GDM}^{22}$.

In our study, GDM patients had significantly high- 
er TSH levels, more frequent anti-TPO and anti-TG antibodies, and RIE. The higher TSH level is associated with an increased prevalence of GDM, and TA is significantly more prevalent in diabetic patients. Our study have shown that a TSH level of $5.33 \mathrm{mU} / \mathrm{l}$ has a sensitivity of $62.9 \%$, a specificity of $78.7 \%$, and a diagnostic accuracy of $75.4 \%$ to predict GDM. Similarly, Karakosta et al. ${ }^{23} \mathrm{dem}$ onstrated that every unit of raise in TSH level is associated with an enhanced risk for GDM (relative risk (RR) is $1.1,95 \%$ confidence interval: 1.0 and 1.2). Ying et al. ${ }^{24}$ found that an increased TSH and TPO antibody positivity is associated with three times more people at risk of developing GDM. Safian et al. ${ }^{25}$ also demonstrated that subclinical hypothyroidism and anti-TPO positivity were more frequent in the GDM (+) group than in the GDM (-) group. In a study including 2333 pregnant women, increased TSH level and positive anti-TPO were associated with a higher risk of GDM progression ${ }^{26}$. A meta-analysis of twenty cohort and case-control studies emphasizes that there is a significant relationship between thyroid antibodies in early pregnancy and GDM. However, the predictive value of thyroid dysfunction is ${ }_{\text {low }}{ }^{27}$. Hornnes et al. ${ }^{28}$ demonstrated that pregnant women with positive TA had reduced glucose tolerance, especially in late pregnancy. Fernandez Soto et al. ${ }^{29}$ also demonstrated that anti-TPO antibody positivity is associated with poor glycemic control and hypothyroidism. Distinctively, Montaner et al. ${ }^{30}$ and Agarwal et al. ${ }^{31}$ did not find any relationship between thyroid autoimmunity and GDM. In this study, we found that TSH levels tended to be higher among patients with positive thyroid antibody. This association was statistically significant for anti-TPO and anti-TG. This result is congruous with the literature ${ }^{6}$.

lodine levels have been studied by the World Health Organization (WHO), United Nations International Children's Emergency Fund (UNICEF), and International Council for Control of Iodine Deficiency Disorders. According to their recommendations severely inadequate $(<50 \mu \mathrm{g} / \mathrm{l})$ mild- to-moderately inadequate (50 and $149 \mu \mathrm{g} / \mathrm{l}$;) adequate, (150 and $249 \mu \mathrm{g} /$ ) more than appropriate (250 and $499 \mu \mathrm{g} / \mathrm{l})$; and extremely higher $(\geq 500$ $\mu \mathrm{g} / \mathrm{l})$ levels of iodine were determined as indicat$\mathrm{ed}^{32}$. RIE is a sensitive determinant of iodine status and daily iodine intake. Physiologic changes in pregnancy, including increased glomerular infiltration and fetal requirements, increase the need for iodine intake, and WHO recommends $250 \mu \mathrm{g}$ iodine intake for pregnant women ${ }^{33}$. Despite the iodination of table salt since 1994, Ankara seems to have insufficient iodine status ${ }^{34}$. A few data have focused on the relationship between iodine insufficiency and GDM in the literature. Vitkova et al. ${ }^{35}$ demonstrated that $88.1 \%$ of women who had diagnosed as pre-gestational or gestational diabetes have iodine deficiency. In our study, RIE was higher in the GDM group, although mean RIE was within a sufficient range for both groups. More studies with a broader population are needed to make decision whether iodine-containing supplements and iodized salt should be given to the patients with GDM.

\section{CONCLUSION}

There is a lack of studies in the literature focusing on the association between thyroid disorders and GDM. Interaction between thyroid and glucose metabolism is apparent. Our study demonstrates that increased TSH levels, RIE, and TA positivity in the first trimester are associated with an enhanced risk of developing GDM. It can be concluded that a universal approach to screen for GDM in the early pregnancy might be advised for pregnant women with thyroid disorders.

\section{REFERENCES}

1. Karakaya BK, Moraloglu O, Findik RB, et al. Evaluation of maternal and fetal stress hormones during the process of birth. Gynecology Obstetrics \& Reproductive Medicine. 2018;24:65-70. [CrossRef]

2. Glinoer D. The regulation of thyroid function in pregnancy: pathways of endocrine adaptation from physiology to pathology. Endocr Rev. 1997;18:404-33. [CrossRef]

3. Krajewski DA, Burman KD. Thyroid disorders in pregnancy. Endocrinol Metab Clin North Am. 2011;40:739-63. 
U.Y. Sert et al. Is There Any Relationship Between Thyroid Function Abnormalities, Thyroid Antibodies and Development of Gestational Diabetes Mellitus (GDM) in Pregnant Women?

\section{[CrossRef]}

4. Leung AM. Thyroid function in pregnancy. J Trace Elem Med Biol. 2012;26:137-40. [CrossRef]

5. Van den Boogaard E, Vissenberg R, Land JA, et al. Significance of (sub)clinical thyroid dysfunction and thyroid autoimmunity before conception and in early pregnancy: a systematic review. Hum Reprod Update. 2016;22:532-3. [CrossRef]

6. Alexander EK, Pearce EN, Brent GA, Brown RS, Chen H, Dosiou C. 2017 Guidelines of the American Thyroid Association for the Diagnosis and Management of Thyroid Disease During Pregnancy and the Postpartum. Thyroid. 2017;27:315-89. [CrossRef]

7. Negro R, Formoso G, Mangieri T, Pezzarossa A, Dazzi D, Hassan H. Levothyroxine treatment in euthyroid pregnant women with autoimmune thyroid disease: effects on obstetrical complications. J Clin Endocrinol Metab. 2006;91:2587-91. [CrossRef]

8. Abbassi-Ghanavati M, Casey BM, Spong CY, McIntire DD, Halvorson LM, Cunningham FG. Pregnancy outcomes in women with thyroid peroxidase antibodies. Obstet Gynecol. 2010;116:381-6. [CrossRef]

9. De Zoysa E, Hettiarachchi M, Liyanage C. Urinary iodine and thyroid determinants in pregnancy: a follow up study in Sri Lanka. BMC Pregnancy Childbirth. 2016;16:303. [CrossRef]

10. Brucker-Davis F, Ferrari P, Gal J, Berthier F, Fenichel P, Hieronimus S. Iodine status has no impact on thyroid function in early healthy pregnancy. J Thyroid Res. 2012;2012:168764. [CrossRef]

11. Kumar A, De Leiva A, Corcoy R. Autoimmunity in Gestational Diabetes Mellitus. Gestational Diabetes. 28: Karger Publishers; 2020; p:234-42. [CrossRef]

12. American Diabetes A. Diagnosis and classification of diabetes mellitus. Diabetes Care. 2011;34(Suppl 1):62-9. [CrossRef]

13. Vitacolonna E, Lapolla A, Di Nenno B, et al. Gestational diabetes and thyroid autoimmunity. Int J Endocrinol. 2012;2012:867415. [CrossRef]

14. Hage M, Zantout MS, Azar ST. Thyroid disorders and diabetes mellitus. J Thyroid Res. 2011;2011:439463. [CrossRef]

15. Perros P, McCrimmon RJ, Shaw G, Frier BM. Frequency of thyroid dysfunction in diabetic patients: value of annual screening. Diabet Med. 1995;12:622-7. [CrossRef]

16. Tosi F, Moghetti P, Castello R, Negri C, Bonora E, Muggeo $M$. Early changes in plasma glucagon and growth hormone response to oral glucose in experimental hyperthyroidism. Metabolism. 1996;45:1029-33. [CrossRef]

17. Kahaly GJ, Hansen MP. Type 1 diabetes associated autoimmunity. Autoimmun Rev 2016;15:644-8. [CrossRef]

18. Umpierrez GE, Latif KA, Murphy MB, et al. Thyroid dysfunction in patients with type 1 diabetes: a longitudinal study. Diabetes Care. 2003;26:1181-5. [CrossRef]

19. Springer D, Jiskra J, Limanova Z, Zima T, Potlukova E. Thyroid in pregnancy: From physiology to screening. Crit Rev Clin Lab Sci. 2017;54:102-16. [CrossRef]

20. Jia $M, W u Y$, Lin B, et al. Meta-analysis of the association between maternal subclinical hypothyroidism and gestational diabetes mellitus. Int J Gynaecol Obstet. 2019;144:239-47. [CrossRef]

21. Murgia C, Orru M, Portoghese E et al. Autoimmunity in gestational diabetes mellitus in Sardinia: a preliminary case-control report. Reprod Biol Endocrinol. 2008;6:24.
[CrossRef]

22. Olivieri A, Valensise H, Magnani F, et al. High frequency of anti-thyroid autoantibodies in pregnant women at increased risk of gestational diabetes mellitus. Eur J Endocrinol. 2000;143:741-7. [CrossRef]

23. Karakosta P, Alegakis D, Georgiou V, et al. Thyroid dysfunction and autoantibodies in early pregnancy are associated with increased risk of gestational diabetes and adverse birth outcomes. J Clin Endocrinol Metab. 2012;97:4464-72. [CrossRef]

24. Ying H, Tang YP, Bao YR, et al. Maternal TSH level and TPOAb status in early pregnancy and their relationship to the risk of gestational diabetes mellitus. Endocrine. 2016;54:742-50. [CrossRef]

25. Safian S, Esna-Ashari F, Borzouei S. Thyroid dysfunction in pregnant women with gestational diabetes mellitus. Curr Diabetes Rev. 2020;16(8):895-9. [CrossRef]

26. Deng S-Q, Chen H-T, Wang D-Y, Liu B, Chen H-Q, Wang Z-L. Maternal Thyroid-Stimulating Hormone Level and Thyroid Peroxidase Antibody Status in the First and Second Trimester of Pregnancy and Their Relationship with the Risk of Gestational Diabetes Mellitus. Maternal-Fetal Medicine. 2019;1:81-5. [CrossRef]

27. Yang Y, Li Q, Wang Q, Ma X. Thyroid antibodies and gestational diabetes mellitus: a meta-analysis. Fertil Steril. 2015;104:665-71 e3. [CrossRef]

28. Hornnes PJ, Rasmussen N, Hegedus L, Kuhl C, Bottazzo GF. Glucose tolerance and incidence of pancreatic islet cell antibodies in pregnancy in women with thyroid autoantibodies. Horm Metab Res. 1991;23:122-5. [CrossRef]

29. Fernandez-Soto L, Gonzalez A, Lobon JA, Lopez JA, Peterson CM, Escobar-Jimenez $\mathrm{F}$. Thyroid peroxidase autoantibodies predict poor metabolic control and need for thyroid treatment in pregnant IDDM women. Diabetes Care. 1997;20:1524-8. [CrossRef]

30. Montaner P, Juan L, Campos R, Gil L, Corcoy R. Is thyroid autoimmunity associated with gestational diabetes mellitus? Metabolism. 2008;57:522-5. [CrossRef]

31. Agarwal MM, Dhatt GS, Punnose J, Bishawi B, Zayed R. Thyroid function abnormalities and anti-thyroid antibody prevalence in pregnant women at high risk for gestational diabetes mellitus. Gynecol Endocrinol. 2006;22:261-6. [CrossRef]

32. World Health Organisation, UNICEF, ICCIDD. Assessment of iodine deficiency disorders and monitoring their elimination: a guide for programme managers 2008 . Geneva: 2007. Available from: https://apps.who.int/iris/bitstream/handle/10665/43781/9789241595827_eng.pdf ;jessionid=64F4F47B3881756D261848E756695EBB?se quence $=1$

33. Gowachirapant S, Jaiswal N, Melse-Boonstra A. et al. Effect of iodine supplementation in pregnant women on child neurodevelopment: a randomised, double-blind, placebo-controlled trial. Lancet Diabetes Endocrinol 2017;5:853-63. [CrossRef]

34. Koyuncu K, Turgay B, Soylemez F. Iodine deficiency in pregnant women at first trimester in Ankara. J Turk Ger Gynecol Assoc. 2019;20:37-40. [CrossRef]

35. Vitkova H, Anderlova K, Radimerska V, Kratky J, Fait T, Jiskra J. Urinary iodine concentrations in pregnant women with gestational and pregestational diabetes mellitus. $17^{\text {th }}$ European Congress of Endocrinology; 2015: BioScientifica. [CrossRef] 